\section{The Determinants of the Life Cycle Stages of Brazilian Public Companies: A Study Based on Financial- Accounting Variables}

\author{
Wando Belffi da Costa ${ }^{\dagger}$ \\ Universidade Federal do Espírito Santo (UFES) \\ Marcelo Alvaro da Silva Macedo $\Omega$ \\ Universidade Federal do Rio de Janeiro (PPGCC/UFRJ) \\ Karen Yukari Yokoyama ${ }^{¥}$ \\ Universidade Federal do Espirito Santo (UFES) \\ José Elias Feres de Almeida* \\ Universidade Federal do Espirito Santo (UFES)
}

\section{ABSTRACT}

This paper analyses the relation between firms' life cycles stages according to Dickinson's (2011) definition and accounting and financial ratios. We applied multinomial logistic regression analysis on a sample of 1,515 observations of public companies listed on BM\&FBOVESPA between 2005 and 2012. Based on the literature about firms' life cycle stages (YAN; ZHAO, 2010; MILLER; FRIESEN, 1984; FAMA; FRENCH, 2001) the accounting and financial ratios used were dividends distribution, leverage, market-to-book, return on equity, firm size and revenue growth. The results show that leverage, dividends distribution, market-to-book, return on equity, firm size and revenue growth could be used as explanatory factors to classify firms' life cycle stages.

Keywords: Life cycle, Accounting ratios, Finance, Brazilian public companies, Capital market.

\section{INTRODUCTION}

The life cycle theory of the firm, originating from the product life cycle theory, albeit traditionally applied to scientific studies associated with the Marketing, Strategy and Management disciplines (YAN; ZHAO,2010), has drawn the attention of international researchers in the accounting and finance disciplines as can be observed in the seminal studies by Miller and Friesen (1980; 1984), Fama and French (2001), De Angelo et al. (2006) and Dickinson (2011).

Generally, studies in the literature use as an analytical tool the multiple linear regression or binary logistic regression from a Life Cycle proxy associated with the Theory of Dividends, such as dividends paid out and capital allocation. These studies assess the relevance and association of the proxies defined with independent variables.

The literature has been presenting the ability of accounting numbers to predict and explain stages of bankruptcy and insolvency (BEAVER, 1966; ALTMAN, 1968; CARDOSO et al., 2010), financial constraints (FAZZARI et al., 1988; FAMA; FRENCH, 1995; DEMONIER, 2013) and future cash flows (SUBRAMANYAM, 1996; BROCHET; NAM; RONEM, 2008).
Corresponding author:

†Universidade Federal do Espírito Santo (UFES).

E-mail: wandob@gmail.com

$\Omega$ Universidade Federal do Rio de Janeiro (PPGCC/UFRJ).

E-mail: malvaro.facc.ufrj@gmail.com

${ }^{¥}$ Universidade Federal do Espírito Santo (UFES).

E-mail: karen.yukari@gmail.com

* Universidade Federal do Espírito

Santo (UFES).

E-mail: Jose.e.almeida@ufes.br

Received: 01/21/2015.

Revised: 03/26/2015.

Accepted: 02/03/2016.

Published Online: 05/02/2017. 
Specialized publications have been addressing the correlation between different life cycle stages of organizations with the characteristics of firms (FAMA; FRENCH, 2001; DE ANGELO et al., 2006, DENIS; OSOBOV, 2008; COULTON, RUDDOCK, 2011), capital structure (OWEN, YANSOM, 2010; WARUSAWITHARANA, 2013), growth opportunity (FAMA; FRENCH, 2001), profitability (WARUSAWITHARANA, 2013) and revenue growth (BULAN, YAN, 2010).

Thus, accounting and financial variables can also have predictive and/or explanatory capacity of the stages of firms' life cycle, that may present different behavior in each of them, motivating the following research question: Which accounting and financial variables can be directly associated with the classification of companies according to the life cycle stage?

The aim of this study is to investigate the accounting and financial variables that can be directly related to the classification of firms according to the life cycle stage. In other words, we seek to empirically identify the accounting determinants of the life cycle stages of listed Brazilian firms, i.e., accounting and financial variables that characterize certain times of corporate life.

To conduct this study we collected a sample containing 1,515 observations between 2005-2012, where each company is classified within a life cycle stage, according to its cash flow characteristics proposed by Dickinson (2011), for subsequent application of the multinomial logistic regression, where each level of the dependent variable is a stage of the life cycle.

Dickinson (2011) demonstrates how combinations of operating, financing and investing cash flows can be used to identify the life cycle stage of firms. From the metrics created, the author analyzes how life cycle stages explain various corporate factors, in particular, profitability patterns (return on net assets, profit margin, asset turnover, variation in returns). The present study expands the seminal study by Dickinson (2011) by verifying accounting and financial factors that explain the propensity of firms to fit into certain life cycle stages. Among these factors, we highlight size, leverage, growth opportunity, return on equity, dividends payout and revenue growth.

Therefore, unlike previous studies, this study contributes to the literature in the Life Cycle Theory of the Firms and in accounting and finance by presenting evidence that accounting variables explain life cycle stages differently according to the evidence of the multinomial logistic regression model.

The article is presented in two parts. First, we address key scientific studies on the association between the life cycle of firms and their accounting and financial ratios and which served as the basis for this work. The second part corresponds to the empirical study conducted, describing the proposed research methodology and the classification method of the adopted life cycle stages, and the construction of the econometric model of multinomial logistic regression and the obtained evidence.

\section{THEORETICAL FRAMEWORK AND DEVELOPMENT OF HY- POTHESES}

Accounting as a source of information for the decision-making by the most various users (Stakeholders), treats the entity as an organization made to operate for an indefinite time. Thus we have two views on indefinite duration of the company. The first one says that, as a result of commitments having different deadlines, new commitments need to be undertaken continuously in the future so that all are met. The second view holds that the company in operation is a company that is adapted to itself through the sale of its assets in the ordinary course of business, i.e., an ordinary liquidation process, rather than a forced liquidation (HENDRIKSEN; BREDA, 1999). 
BBR

14,3

To maintain this indefinite duration, the company must overcome internal and external factors to evolve. Miller and Friesen (1980) draw an analogy between the life cycle of firms with the life cycle of primitive organisms. The authors saw that both are complex organis$\mathrm{ms}$. The organizational adaptation is a process that results in the growth or dissolution of the company. One factor that influences the organizational adaptation is time. Understanding the time dimension in the organization helps to understand the process of adaptation and the interrelations between decisions and events (MILLER; FRIESEN, 1980).

The research of firms' life cycle investigates the changes that the company suffers over time, as organizational changes occur in predictable patterns characterized by developmental stages. Transitions are expected insofar as simple and young organizations become more complex and older (NECYK; SOUZA; FREZATTI, 2007). According to Greiner (1998), organizations go through five distinct stages of evolution, and each contains a relatively calm period of growth that ends with a crisis in management, with the previous phase strongly influencing the later stage.

The life cycle of firms can be compared to the life of animals. The organizational life cycle is a divided model in stages through which a company can go through during its existence (COSTA; BOENTE, 2012). However, unlike animals' life cycle, the cycle of organizations is not necessarily sorted into a chronological order. Thus, a company in the birth stage can move to its stage of decline. Miller and Friesen (1984) found that, even though organizations may present a tendency to evolve into a linear sequence over its life cycle stages, nonlinear evolutions can occur, since in each life cycle stage companies present special characteristics.

The life cycle of products is characterized by progression, i.e., from the birth to the decline stages. However, the company is a portfolio of various products. New products innovation, expanding into new markets and structural changes can cause the company to move between the life cycle stages in a non-sequential manner. For this reason, the life cycle of the company can be cyclical in nature, and the main objective of the company is to remain at the Growth and Mature stage where the return and risk structure is optimized (DICKINSON, 2011).

According to Gort and Klepper (1982), the life cycle stages can be classified into five stages, but companies do not necessarily need to go through each stage in order: I) The first stage, named as the "Introduction", also termed as Birth, corresponds to the stage where the company seeks opportunities to establish themselves in the market, in some cases, through the insertion of new products on the market where other companies will copy it. The time period in the Birth stage will depend on the speed at which other companies will copy the product and launch it on the market; II) The second stage: "Growth", the company is focused on investments, the number of competitors increases. This stage is characterized by the acceptance of the market towards the company's products, i.e., the market is not yet saturated by the new product inserted therein; III) In the third stage, "Mature", competition among participants is more defined, and the number of new entrants in the market is close to zero, and this suggests that the distribution of revenue (market-share) occurs among participants; IV) The fourth stage "Shake-out", or Turbulence, the entry of new entrants in the market is negative and may result in the last stage of the life cycle; V) The last stage is called "Decline", which corresponds to the Decline phase, where entrants into the market is zero, and obtaining revenue to cover costs and keep the activities is unstable (GORT; KLEPPER, 1982).

Analyzing the life cycle in the organizational context is a difficult task (DICKINSON, 2011). Other authors such as Miller and Friesen (1980) and Almeida and Luz (2010) analyzed the company's life cycle at the level of management, planning and product or focusing on the contingency theory. However, Dickinson (2011) proposed a proxy to identify the life cycle stages of firms through accounting variables. 
Dickinson (2011) classifies the life cycle of firms through the "organic" methodology where the life cycle stage is defined by the performance and allocation of resources as opposed to arbitrary allocation. Also according to Dickinson (2011), the main advantage of using the cash flow pattern proxy is the entire financial information of the organization's information sets, i.e., operating, investment and financing instead of a single metric to determine the life cycle. The use of variables such as age of the company, sales growth, capital expenditures, dividends payout or a compound of these variables requires the consideration of a prior hypothesis regarding the underlying distribution of life cycle membership, i.e., a uniform distribution of the life cycle stages is assumed. On the other hand, cash flow patterns are the organic results of a company's operations and foster better congruence with the economic theory (DICKINSON, 2011).

According to the theoretical foundation of firm life cycle, organizations undergo consistent patterns of development over time (AUZAIR, 2010). In this sense, some studies indicate expected behavior in relation to accounting and financial ratios for the various life cycle stages.

Companies that are in the Birth stage are initiating their introduction in the market. Often they need to face strong competition from established organizations, demanding capital to steady themselves in the market and move to the next stage (GORT; KLEPPER, 1982). Their structures are simple and centralized. Decisions are made by the founder, being guided more by intuition than analytical models and few opinions are taken into account in key decisions (NECYK; SOUZA; FREZATTI, 2007).

Thus, in early stages (Introduction and Growth), companies are expected to have high growth opportunities, accompanied by high expenditures, but with little ability to finance themselves through internal resource, so they will seek external financing in a greater measure. As they reach maturity, companies can generate resources internally by profit accumulation, relying less on external financing that increases leverage (OWEN, YANSOM, 2010; WARUSAWITHARANA, 2013).

At the growth stage, the company's structure tends to become more specialized, more effort is expended in collecting and processing information about the competitive environment (monitoring) to control financial performance (NECYK; SOUZA; FREZATTI, 2007). The growing company, can thus focus on making investments, the acquisition of subsidiaries and sales growth (DRAKE, 2013).

According to Fama and French (2001), there is evidence of correlation between growth opportunity and the life cycle of firms, and this correlation indicates that firms in development would have greater growth opportunities in relation to mature firms.

Growth and Maturity are the stages of the life cycle in which companies aspire political arrangements to maintain environmental stability, although this stage is characterized by a decrease in innovation. The structure is more professional (NECYK; SOUZA; FREZATTI, 2007). When the company is in the Maturity stage, it becomes more conservative, less inclined to risk and innovation, thus enabling greater freedom over the decision to distribute dividends or not. Unlike the early stages, now firms are able to generate resources internally through profit accumulation and may turn to the expansion process (OWEN, YANSOM, 2010; WARUSAWITHARANA, 2013).

One of the research streams of the Life Cycle Theory, the Theory of Dividends (FAMA, FRENCH, 2001, DE ANGELO et al., 2006; DENIS, OSOBOV, 2008; COULTON, RUDDOCK, 2011), suggests that the effects of dividends payout and retained earnings vary with firms life cycle, working as proxies for the cycle itself. According to this strand, companies in early stages have a lower chance of internal resource generation, lower profitability and, on the other hand, greater investment needed to enter the market, and are therefore more likely to retain earnings. Having achieved Maturity, a higher profitability is expected, thus generating greater resources for their investment needs. Consequently, excess resources will be distributed to shareholders as dividends. 
BBR

14,3

At the Shake-out stage firms face adverse period of operation due to changes in the environment, as in the event of a crisis, leading to the reduction and reconfiguration of the market and therefore, to the moment of probable decline in sales and profitability. This stage usually precedes the decline stage, but it can migrate or not to this stage, since the firm will still seek to change its strategy in order to revitalize the company (DRAKE, 2013). When the company is at the Shake-out stage, it needs to change behavior and strategy patterns so it can go back to its previous stage, when it was profitable (LESTER; PARNELL; CARRAHER, 2003).

The Decline stage, can be considered as a critical moment for the company's survival, because at this stage the company has negative revenue growth, with decreased responsiveness to challenges (NECYK; SOUZA; FREZATTI, 2007). Failure to meet external demands at an earlier stage led the company to a period of decline, in which it experiences a lack of profit and a reduction in market share (LESTER; PARNELL; CARRAHER, 2003). The Decline stage can therefore occur, after any other stage, for example, directly after the Introduction stage, if the firm fails to establish itself in the market (DICKINSON, 2011).

According to the finance literature, whereas firms in the Growth stage present overall, high sales growth rates (BULAN; YAN, 2010), and mature firms present stable rates, since they are established in a market, with widely known product and competitors also established, in the Decline stage, companies are expected to present stagnant or decreasing sales revenue.

In this study, the hypotheses developed to examine the relationship between the life cycle stages and accounting and financial ratios are presented together because the econometric model (multinomial logit) explains the probability of a firm being in a given stage of the cycle and the effects of the ratios compared to the Maturity stage.

H1: Companies in the early stages (Introduction and Growth) are smaller in size and profitability, with higher financial leverage and growth opportunities than those in the mature stage.

$\mathrm{H} 2$ : Companies in stages of Turbulence and Decline present greater negative variations in sales and have less opportunities for growth and profitability in relation to firms in the Maturity stage.

H3: Firms in the Maturity stage have higher dividends payouts compared with companies in other stages of life cycle.

H4: Firms classified in the Growth stage have greater positive variations in sales (growth) if compared with companies in the Maturity stage.

\section{RESEARCH DESIGN}

To empirically verify the theoretical assumptions on firm's life cycle we resorted to the use of accounting and financial ratios of listed Brazilian firms in a multinomial logistic regression, estimated by the maximum likelihood method.

The multinomial logistic regression is used to analyze categorical dependent variables (greater than two categories), comparing themselves to multiple groups, from binary logistic regressions between each group and a reference category. Thus, we compute the classification probabilities of the observations in each group by the odds ratio.

Although the life cycle stages are ordinal in nature at first, so that it would follow progressively from Introduction to Decline, Miller and Friesen (1984) point out that companies can fall back between stages, therefore, with no sequential order being absolute.

Thus, due to the dynamics of firms and the very environmental factors to which they are subject, the sequential progression of firms life cycle stages may not be suitable. For example, companies in the Introduction stage can go directly to the Decline and the bankruptcy stage, as well as a mature company, in developing a new product, go back to the Growth stage. 
Besides the theoretical point of view, by virtue of the type of classification adopted here and limitations in the availability of data, as well as the possible impact of the 2008 crisis on the behavior of the sample, we cannot ensure the use of observations that antecede the assumptions of validity of the ordinal regression, whatever the existence of proportional odds ratio between pairs of successive categories. Thus, the adoption of multinomial logistic regression, which does not presuppose the existence of order among the categories, seems to be suitable for the research purposes.

We collected accounting and financial data available from Economática and Thomson One of Brazilian public companies listed on the São Paulo Stock Exchange (BM\&FBOVESPA), covering annual observations from 2005 to 2012. Data were extracted from the consolidated financial statements and in the absence of these, from non-consolidated reports.

We excluded financial institutions from the sample, since they have specific accounting standards and regulatory prerogatives, as well as companies with incomplete or unavailable data. Finally, in the sample we considered companies with data available in each year of analysis, regardless of whether they present data for other periods.

The sample was also treated for the presence of outliers, we excluded observations with standard deviations greater than 3 of the normalized data. The final sample consists of 313 companies, totaling 1,515 valid observations, organized on pooled data.

Table 1 shows the development of the database and stages of sample treatment.

The data for the dependent variable classification were extracted from the Cash Flow Statement (CFS) accounting report that became mandatory for public companies or with equity above 2,000,000 (BRL), only from 01.01 .2008 , by the law $11.638 / 07$, however, some companies released this statement already voluntarily in prior periods or due to regulatory requirements. Companies that did not have this information were excluded from the sample.

Among the main proxies of firm life cycle highlighted in the accounting literature: dividend payouts, retained earnings on assets, revenue growth and the age of the company. However, for this study, we adopted the classification method proposed by Dickinson (2011), based in an integrated manner, on the behavior of firms' cash flows regarding their operating, investing and financing activities, whereas the combination of cash flows covers various aspects/conditions of organizations.

Through the composition of the cash variation signal (Operating, Investing and Financing), we classified each company at a certain stage of the life cycle, as in the following Table 2:

According to Dickinson (2011), on Introduction, the operating cash flow is negative due to lack of full knowledge of start-ups regarding the dynamics of revenue and costs. At the same time, companies will make large investments (negative sign on the ICF) to support the firm's entry in the market and will therefore, need external financing (positive sign on the FCF). Growing businesses will make major investments to expand (negative sign on the ICF) and the assertion in the market, thus requiring high external financing (positive sign on the FCF). During this period, the profit margin will increase, positively impacting the operating cash flow.

During Maturity, firms will have greater knowledge of the market and its operations leading to maximization of profit (positive OCF); On the other hand, growth opportunities tend to stabilize whereas the maintenance costs of assets grow, negatively impacting on investing cash flow. However, firms in the mature stage will distribute their profits to the shareholders in the form of dividend payouts and will prioritize for funding with internally generated resources (positive FCF). 
Table 1. Development of database

\begin{tabular}{ll}
\hline Panel A - Total of companies & 896 \\
\hline Total of companies & $(79)$ \\
(-)Financial and funds sectors & $(163)$ \\
(-)Companies with null sector on Economática & $(341)$ \\
(-)Companies with incomplete data & 313 \\
(=)Total of companies in the sample & \\
Panel B: Processing of data for use in model & 87.808 \\
Raw information & 69.384 \\
(-)Empty cells & $(1.759)$ \\
(-)Outliers and observations above or below three standard deviations & 16.665 \\
(=)Total of observations for the model & 1.515 \\
Observations per variable (16.665 observations / 11 variables ) &
\end{tabular}

Table 2. Life Cycle Classification based on Dickinson (2011, p. 1974)

\begin{tabular}{|c|c|c|c|c|c|c|c|c|}
\hline Cash Flow & \multicolumn{8}{|c|}{ Composition of signals for Classifying Life Cycle Stages } \\
\hline Operating (OCF) & - & + & + & + & - & + & - & - \\
\hline Investing (ICF) & - & - & - & + & - & + & + & + \\
\hline Financing (FCF) & + & + & - & + & - & - & + & - \\
\hline Life Cycle: & Birth & Growth & Maturity & & lake- & & & \\
\hline
\end{tabular}

Companies in the decline stage however, face growth and prices falls, resulting in a negative operating cash flow. Therefore, in order to meet its obligations, these firms are expected to be focused on renegotiation/payment of debts, demanding therefore, the liquidation of assets, consequently generating positive variation on investment.

Regarding the period of Shake-out, Dickinson (2011) did not find in the economic literature a consolidated theory as to its characteristics. We assume, therefore, that the impact of cash flows will vary from case to case, and the stage will be classified by exclusion of others, i.e., for positive or negative variation situations for all activities, for situations where the financing activity is negative.

Next, Table 3, presents the number of classified observations at each life stage after applying the method by Dickinson (2011), i.e., from the signals composition of cash variation drawn from the statements of companies' cash flows, as presented in Table 3, totaling 1,515 observations. We can observe that the greater frequencies, as expected, occur in stages of Growth and Maturity.

A possible bias arising from this distribution is considered in the developed models.

To illustrate the non-linear change of firms life cycle stages comprising the sample in this study, we developed Table 3. Out of a total of 313 companies of the sample comprising the 1,515 observations, 84 did not change their life cycle stage, representing 276 observations. Companies identified in the Introduction stage, $41 \%$ migrated to the Growth stage. Those initially identified in the Growth stage, 55\% remained in this stage and 36\% migrated to Maturity. Companies that were in the Maturity stage, $62 \%$ remained in this stage and 30\% moved to the Growth stage. Companies that were in the Shake-out stage, $29 \%$ remained there, $28 \%$ migrated to the Growth stage and $28 \%$ migrated to the Maturity stage. Companies that were in the Decline stage, $36 \%$ remained in this stage and $29 \%$ returned to the Maturity stage.

As noted by Costa and Boente (2012) and Miller and Friesen (1984), the behavior of fir$\mathrm{ms}$ in the various life cycle stages does not follow an erratic pattern. It is possible for companies to change to between different stages over the years due to different characteristics 
and strategies. However, as expected this variation occurs largely between the neighboring stages in the sample. As shown in Table 4, considering companies with observations over at least two years in a row, almost $80 \%$ of the companies that were in the Introduction stage in a year remained in this stage or moved to the Growth or Maturity stages. The same reasoning applies to the growth stage, since $91 \%$ of companies that were in this stage in a given year either in it or moved to the mature stage. For Maturity, $92 \%$ of companies remained either remained in this stage or moved to growth. In relation to Shake-out stage, we noted that $85 \%$ of companies either remained in this stage or moved to Maturity or Growth. Finally, we observe that $96 \%$ of companies in the decline stage either remained for another year in this stage or returned to the Shake-out or Mature stages.

Thus, it is noticed that the possibly erratic classification of cash flows did not cause such an erratic variation in the classification of companies in the various life cycle stages. Based on the collected variables, we applied a multinomial logistic regression model in order to test the potential determinants of the classification probability of enterprises in each life cycle stage, namely: Introduction, Growth, Mature, Shake-out or Decline.

The employed logistic regression uses the binomial distribution to examine the simultaneous impact of multiple explanatory factors in the probability of "success" against the chance of "failure" (FÁVERO et al., 2009). We adopted the Mature stage as a reference dependent variable, which the other categories will be analyzed against.

In the multinomial regression we use the c-1 logit functions to apply the regression, with $\mathrm{c}$ being the number of categories of the dependent variable, so that the overall function of the conditional probability of the model for the 5 categories, according to Hosmer and Lemshow (2000, p. 263), is presented in the equation 1:

$$
P(Y=j / X)=\frac{e^{g_{j}(X)}}{\sum_{k=0}^{c-1} e^{g_{k}(X)}}
$$

Considering these hypothesis, we developed the following econometric model:

$P(C I C L O D E V I D A)=\beta_{0}+\beta_{1} D V P L_{i t}+\beta_{2} D T A_{i t}+\beta_{3} R O E_{i t}+\beta_{4} M T B_{i t}+\beta_{5} T A M_{i t}+\beta_{6} C V_{i t}+\varepsilon_{i t}$

Where:

P(LIFE CYCLE): Categorical dependent variable, which can assume the following values:

1- Introduction, 2- Growth, 0 - Mature, 3-Shake-out, 4- Decline.

$\mathrm{DIV}_{\mathrm{it}}$ : Dividends paid by the company $\mathrm{i}$ at time $\mathrm{t}$ divided by the shareholders' equity (book value).

$\mathrm{LEV}_{\mathrm{it}}$ : Debt-to-Asset, variable that measures the degree of leverage of company $\mathrm{i}$ at the time $t$, calculated by dividing the total liabilities by the total assets.

$\mathrm{ROE}_{\mathrm{it}}$ : Return on equity, calculated by dividing net income by the shareholders' equity of firm $\mathrm{i}$ at time $\mathrm{t}$.

MTB $_{i t}$ : Market-to-Book, growth opportunity Proxy. Calculated by the market value over shareholders' equity of firm i at the time $t$.

$\mathrm{SIZE}_{\mathrm{it}}$ : Size of the firm $\mathrm{i}$ at the time t. Calculated by the natural logarithm of the total assets.

$\mathrm{REVG}_{\mathrm{it}}$ : Revenue growth. Dummy for income variation between times $\mathrm{t}-1$ and $\mathrm{t}$, with 1 for positive variations (increased sales) and 0 for negative variations (reduction in sales). The option for the binary transformation of the sales growth variable due to identified collinearity problems. The maintenance of the variable is necessary since the growth variable is essential to identify firm financing decision patterns, 
BBR

14,3

312

Table 3. Total of Analyzed Observations

\begin{tabular}{lcc}
\hline Life cycle stage & $\mathrm{N}^{\circ}$ observations & $\%$ \\
\hline Introduction & 50 & $3 \%$ \\
Growth & 660 & $44 \%$ \\
Mature & 659 & $43 \%$ \\
Shake-out & 118 & $8 \%$ \\
Decline & 28 & $2 \%$ \\
Total & 1515 & $100 \%$ \\
\hline
\end{tabular}

differentiating, especially companies going through Growth and Mature (BULAN; YAN, 2010).

The hypotheses developed from the previously referenced literature resulted in the following table of expected beta coefficients for each independent variable (Table 5), having as reference the Mature stage.

The NA cells refer to the signs either inconclusive or not contemplated in the consulted literature, i.e., in which the analysis could not be applied due to lack of theoretical/empirical basis to support a hypothesis to be tested related to the life cycle stage.

\section{RESULTS}

\subsection{DESCRIPTIVE STATISTICS}

In Table 6, next, we present the descriptive statistics of each independent variable for each life cycle stage. We must highlight that the analysis is indicative only, since the statistical difference was not assessed.

We note that the Maturity stage concentrates the greater volume of dividend payouts and increased profitability. in Shake-out and in Decline, the Market-to-Book values are lower. However, unlike the expected, it is in the Mature stage that we observe the highest average value for the Market-to-Book. In relation to leverage, we observe that the highest values are found in the early stages. Finally, in relation to the size, companies in the Mature stage are smaller on average.

As for the dichotomous variable revenue growth, we observe that almost $90 \%$ of companies in the Growth stage present positive variations in sales, whereas almost $60 \%$ of companies in the Decline stage present negative variations in sales.

Thus, generally speaking, these values point to a variable behavior consistent with the formulated hypotheses which will be analyzed by multinomial logistic regression.

To strengthen such understanding, we proceeded to a Variance Analysis - ANOVA, which sought to analyze whether there was a statistically significant difference of the accounting ratios between companies in different life cycle stages. In the case of differences being observed, we would have evidence that these indicators could have different behavior depending on the life cycle stage in which the company was. The p-values found for each ratio were the following: DIV $(<0.001), \operatorname{LEV}(<0.001)$, ROE $(0.019)$, MTB $(0.005)$ and SIZE $(<0,001)$. Thus, it is clear that in all cases we have a statistically significant difference, at $1 \%$ level, in the behavior of the analyzed ratios between companies of different life cycle stages.

\subsection{RESULTS OF THE MULTINOMIAL LOGISTIC REGRESSION}

First, we analyzed the assumptions and validity of the model fitting. The correlation matrix, Table 7, does not show high values for the correlations between the 
Table 4. Sequence of the life cycle stages per companies

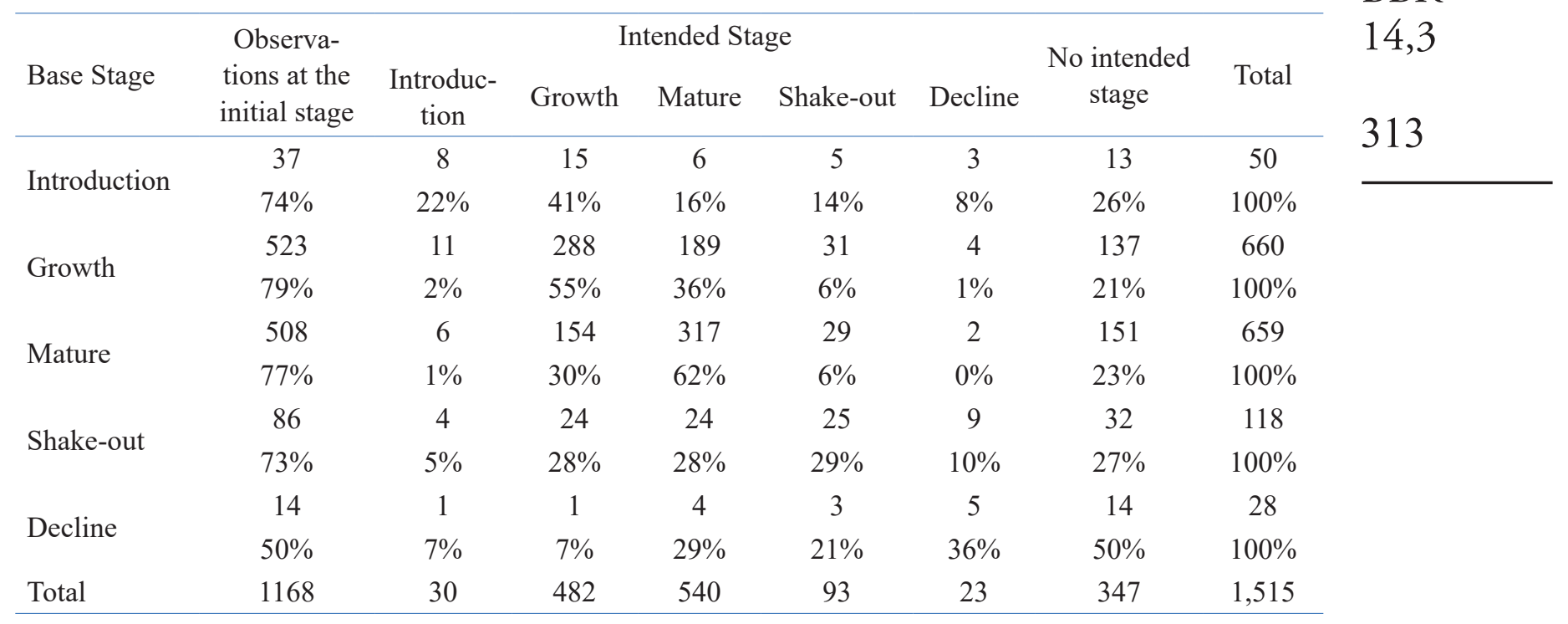

independent variables, being the highest value in module represented by the correlation between DIV and MTB (0.659). Thus, we observe that there is no evidence of problems of multicollinearity between the independent variables.

The log likelihood (-211) test is one of the most used methods to verify whether the quality of model fitting (PETRUCCI, 2009) is consistent when comparing the model with only the intercept with the model with variables. Considering the interpretation that the smaller it is, the better, we observe that for the model there was a decrease in the log likelihood value of -211 (from 0.003361 to 0.003016 ). Therefore, the combination of model variables results in improved predictive power in relation to the model with only the constant.

The existence of a relationship between the dependent variable (in 5 levels) and the combination of independent variables is also corroborated by the Chi-square test. The p-value lower than $1 \%$, indicates that the null hypothesis is rejected, that there is no statistical difference between a model with and without explanatory variables. The $\mathrm{p}$-value lower than $1 \%$ indicates that the null hypothesis (there is no statistical difference between a model with and without explanatory variables) is rejected. Finally, we observe that the model provides a Nagelkerke's pseudo- $\mathrm{R}^{2}$ of $22.9 \%$, showing the capacity of explanation of the dependent variable (life cycle) by the independent variables (accounting and financial ratios).

As stated in the research design section, we analyze the multinomial regression results based on the reference category, i.e., the classification probability in the Mature stage.

Each variable was then analyzed, regarding the signal of the coefficients of determination beta (B) and its significance (p-value), according to Table 8 .

Based on the results presented in Table 8, we observe that for the Introduction stage the variables dividend, leverage, profitability and size are significant. Moreover, it is clear that only the leverage variable has a positive sign. This indicates that the greater the leverage the greater the probability of a company being classified in the Introduction stage rather than the Mature stage. Thus, we disclose that Introduction stage companies have more leverage when compared with those in the Maturity stage. In addition, the greater the dividends paid out, the return on equity (ROE) and size, the smaller the probability of the company being classified in the Introduction stage, in face of the Mature stage. This result indicates that companies in the Introduction 
BBR

14,3

stage have lower dividends, ROE and size when compared with companies in the Mature stage. Thus, we perceive that the hypotheses $\mathrm{H}_{1}$ and $\mathrm{H}_{3}$ can be accepted, confirming what is found in the literature on life cycle stages.

In the analysis of the Growth stage results we observe that the variables dividends, leverage, ROE and revenue growth are significant, with the variables leverage and revenue growth having positive sign. This means that in relation to the dividends paid out, ROE and leverage, companies in the Growth stage present a similar behavior to that of companies in the Introduction stage. However, in relation to revenue growth we noticed that companies with positive variation in sales have higher probability of being classified as in the Growth stage instead of in the Mature stage. In other words, this shows that companies in the Growth stage have greater positive variation (increase) in sales than companies in the Mature stage. Based on these results, hypotheses $\mathrm{H}_{1}, \mathrm{H}_{3}$ and $\mathrm{H}_{4}$ are accepted.

For these first two stages we observe that part of the $\mathrm{H}_{1}$ hypothesis could not be confirmed. This is so because the MTB variable, representing the future growth opportunities, was not significant in any of the early stages. In addition, the part $\mathrm{H}_{1}$ on size could only be confirmed for the Introduction stage.

For the Shake-out stage, we observe that all the variables, except for revenue growth, are significant, with the variables dividends paid out, profitability, MTB and size having negative signs, and only the leverage variable has a positive sign. This means that the higher the dividends paid out, profitability, future growth opportunities and the size, the smaller the probability that the company being classified in the Shake-out stage, in face of the Mature stage. Which in turn, indicates that companies in the Shake-out stage pay less dividends, have lower profitability, future growth opportunities and size when compared with companies in the Mature stage. For leverage, we see the exact opposite, i.e., companies in the Shake-out stage have greater levels of debt. This signals to hypotheses $\mathrm{H}_{2}$ and $\mathrm{H}_{3}$ being accepted. However, the results show a significant unexpected relationship (not contemplated by the theory) between the Shake-out stage and size and leverage. This may be showing that smaller companies are more susceptible to the Shake-out stage and one of the ways to this stage is through uncontrolled debt.

Finally, compared to the Decline stage, we observe that only the variables profitability, MTB and revenue growth appeared as significant, with all the sign being negative. This result shows that in the Decline stage financial problems are represented by low profitability, few future growth opportunities and negative variation (reduction) of sales, which confirms hypotheses $\mathrm{H}_{2}$.

In an analysis of all the life cycle stages in relation to the distribution of dividends, we observe that, except for the Decline stage, it is confirmed that companies with more paid out dividends are more likely to be classified in the Mature stage. In other words, companies at this stage actually distribute more dividends, however, this was not true for the Decline stage, where the coefficient was not significant, i.e., there is no difference between the level of dividend distribution from the stages of Mature and Decline. This behavior may be motivated due to the accumulated cash being distributed to the shareholders, because the company no longer has compatible profitability with its continuity or future growth opportunities. This may even justify a positive coefficient of this variable and its significance at the $10 \%$ level.

Table 9 shows the summary of the main results of this study, as regards to the comparison between the signs expected and those found for the coefficients of the independent variables, and in relation to the hypotheses previously formulated. 
Table 5. Expected Signs from the Coefficients of the Variable

\begin{tabular}{lcccccc}
\hline Variable & & Betas & Introduction & Growth & Shake-out & Decline \\
\hline Dividends & DIV & $\beta 1$ & - & - & - & - \\
Leverage & LEV & $\beta 2$ & + & + & NA & NA \\
Return on Equity & ROE & $\beta 3$ & - & - & - & - \\
Market-to-book & MTB & $\beta 4$ & + & + & - & - \\
Size & SIZE & $\beta 5$ & - & - & NA & NA \\
Revenue Growth & REVG & $\beta 6$ & NA & + & NA & - \\
\hline
\end{tabular}

Table 6. Descriptive Statistics: Mean and Standard Deviation

\begin{tabular}{lccccccc}
\hline \multirow{2}{*}{ Life cycle } & & DIV & LEV & ROE & MTB & SIZE & REVG \\
\hline \multirow{2}{*}{ Introduction } & Average & 0.0122 & 0.6204 & -0.5314 & 2.2956 & 13.9591 & \multirow{2}{*}{$64 \%$} \\
& Standard Deviations & 0.0332 & 0.2277 & 1.2494 & 3.0374 & 1.6067 & \\
\multirow{2}{*}{ Growth } & Average & 0.0486 & 0.5726 & -0.072 & 3.2696 & 14.8103 & \multirow{2}{*}{$87.88 \%$} \\
& Standard Deviations & 0.0921 & 0.1711 & 2.6206 & 9.8531 & 1.5684 & \\
\multirow{2}{*}{ Mature } & Average & 0.1879 & 0.5232 & 0.1046 & 3.5239 & 14.8089 & \multirow{2}{*}{$81.94 \%$} \\
& Standard Deviations & 1.4171 & 0.1829 & 2.0340 & 11.5888 & 1.6306 & \\
\multirow{2}{*}{ Shake-out } & Average & 0.0497 & 0.5464 & 0.0192 & 1.6998 & 14.2523 & \multirow{2}{*}{$69.49 \%$} \\
& Standard Deviations & 0.1156 & 0.2306 & 0.5032 & 2.0113 & 1.4396 & \\
\multirow{2}{*}{ Decline } & Average & 0.0663 & 0.4997 & -0.1253 & 0.8640 & 14.0013 & \multirow{2}{*}{$39.29 \%$} \\
& Standard Deviations & 0.2537 & 0.2204 & 0.6919 & 0.9468 & 0.9400 & \\
\hline
\end{tabular}

Notes: DIV: Dividends paid out over equity; LEV: Leverage (debt-to-asset); ROE: Return on Equity; MTB: growth opportunity (market-to-book); SIZE: Size of firms (ln of total assets); REVG: percentage of companies with positive growth in sales (growth/ increase).

It is noticed that, as expected, the leverage coefficient was positive in the early stages (Introduction and Growth) of the life cycle. This corroborates the idea by Owen and Yansom (2010) and Warusawitharana (2013) who argue that only in the Mature stage can companies accumulate sufficient profits to use internal sources (organics) of financing. In other words, it supports the assumption that in these stages the company needs resources to carry out its operations and to finance its expansion (making productive investments), but it does not generate sufficient internal funds yet. Moreover, note that we found an unexpected positive sign for the Shake-out stage, which can represent that the debt can be one of the reasons for the company to be in this stage.

With respect to growth opportunities, measured by MTB, we notice that there is no significance for the early life cycle stages and that in the Shake-out and Decline stages the sing that was found was negative as expected.

Thus, we do not confirm the evidence mentioned by Fama and French (2001) of greater growth opportunities in the early life cycle stages. However, the results were consistent for the stages of Shake-out and Decline, because as expected, growth opportunities proved limited in these stages of the life cycle in relation to the Maturity stage, corroborated by the negative sign of the variable coefficient MTB.

Regarding the distribution of dividends, except for the Decline stage, in all others we found a negative sign is found, as expected. With this, there is the possibility of partially confirming acceptance of hypothesis $\mathrm{H}_{3}$ (except for the Decline stage). This confirms the theory of Dividends for the life cycle (FAMA, FRENCH, 2001, DE ANGELO et al., 2006; DENIS, OSOBOV, 2008; COULTON, RUDDOCK, 2011), 
BBR

14,3

316

Table 7. Correlation matrix of the variables

\begin{tabular}{|c|c|c|c|c|c|c|c|c|c|}
\hline & DIV & & LEV & & ROE & & MTB & & SIZE \\
\hline DIV & 1 & & & & & & & & \\
\hline LEV & 0.086 & $* *$ & 1 & & & & & & \\
\hline ROE & -0.579 & $* *$ & -0.133 & $* *$ & 1 & & & & \\
\hline MTB & 0.659 & $* *$ & 0.236 & $* *$ & -0.508 & $* *$ & 1 & & \\
\hline SIZE & -0.012 & & 0.223 & $* *$ & 0.058 & $*$ & -0.55 & $*$ & 1 \\
\hline
\end{tabular}

since in this theory companies in the early stages would have a greater propensity to retained earnings (lower propensity to dividend distribution). However, in the life cycle stages which point financial problems (Shake-out and Decline) we observed a significant reduction of dividends only in Shake-out. Perhaps this shows that this stage really is revealing of financial problems that can be solved, however the decline stage may be pointing to the end of the company or business, where the distribution of dividends is not affected, despite reduced profitability, since the accumulated cash can afford to maintain the level of distribution of the Mature stage.

With regard to profitability, we observe that in all cases, exactly as expected, the sign was negative, indicating that in the Mature stage, companies present their best time in terms of profits. This is because it is expected that in the early stages companies are establishing themselves in the market and thus with reduced gains. In the Shake-out and Declines stages however, the financial and/or marketing lead companies to present reduced profits.

In the revenue growth analyses it is clear that the signs are in line with expectations, i.e., for Growth stage we see a sharp increase in sales, whereas in the Decline stage we see reduced sales. This corroborates with what was said by Bulan and Yan (2010) on the high rates of revenue growth for companies in the Growth stage and stagnant or decreasing revenues, for companies in the Decline stage.

Finally, with respect to size, we observe, as expected, that the sign for the Introduction stage is negative, showing that companies in their early stages are smaller. However, this does not apply to the Growth stage. In this case, the results show no statistically significant differences in size between companies in this stage and Mature. An interesting point was the sign found for the variable size in the Shake-out stage. The results show that companies in critical moments are smaller. This may indicate that the smaller ones within the sample may be more likely to enter this stage.

Robustness analysis of the results were performed taking into account the alternation between the variables REVG, MTB and SIZE. This was done because of possible collinearity problems between variables, which could not have been indicated by the correlation analysis. In a first model, we removed only the variable REVG, and no significant changes were observed in the results, except that the variable DIV was no longer significant at $10 \%$ in the Decline stage.

In a second model, we removed only the variable MTB, and again no significant changes were observed in the results, except for the variable REVG that became significant at $5 \%$ in the Shake-out stage. Finally, in a third model, we removed the variables REVG and MTB, and once again no significant changes were observed in 
Table 8. Model Regression Results

$$
P(L I F E C Y C L E)=\beta_{0}+\beta_{1} D I V_{i t}+\beta_{2} L E V_{i t}+\beta_{3} R O E_{i t}+\beta_{4} M T B_{i t}+\beta_{5} S I Z E_{i t}+\beta_{6} R E V G_{i t} \quad 14,3
$$

\begin{tabular}{|c|c|c|c|c|c|c|c|c|c|}
\hline \multicolumn{5}{|c|}{ Stage: Introduction } & \multicolumn{5}{|c|}{ Stage: Growth } \\
\hline Variables & B & & p-valor & $\operatorname{Exp}(B)$ & Variables & B & & p-valor & $\operatorname{Exp}(B)$ \\
\hline Intercepto & 0.583 & & 0.707 & & $\begin{array}{l}\text { Intercep- } \\
\text { to }\end{array}$ & -1.348 & $*$ & 0.018 & \\
\hline DIV & -25.946 & $* *$ & $<0.001$ & $\begin{array}{l}5.395 \\
\text { E-12 }\end{array}$ & DIV & -5.824 & $* *$ & $<0.001$ & 0.03 \\
\hline LEV & 3.308 & $* *$ & $<0.001$ & 27.320 & LEV & 1.935 & $* *$ & $<0.001$ & 6.922 \\
\hline ROE & -0.612 & $* *$ & 0.001 & 0.542 & ROE & -0.501 & $* *$ & 0.004 & 0.606 \\
\hline MTB & -0.099 & & 0.190 & 0.906 & MTB & 0.012 & & 0.406 & 1.012 \\
\hline SIZE & -0.248 & $*$ & 0.018 & 0.780 & SIZE & 0.013 & & 0.736 & 1.013 \\
\hline REVG & -0.459 & & 0.170 & 0.632 & REVG & 0.643 & $* *$ & $<0.001$ & 1.902 \\
\hline \multicolumn{5}{|c|}{ Stage: Shake-out } & \multicolumn{5}{|c|}{ Stage: Decline } \\
\hline Variables & B & & p-valor & $\operatorname{Exp}(B)$ & Variables & $\mathrm{B}$ & & p-valor & $\operatorname{Exp}(B)$ \\
\hline Intercepto & 1.657 & & 0.093 & & $\begin{array}{l}\text { Intercep- } \\
\text { to }\end{array}$ & 2.851 & & 0.148 & \\
\hline DIV & -2.893 & $*$ & 0.024 & 0.055 & DIV & 2.361 & & 0.096 & 10.596 \\
\hline LEV & 1.804 & $* *$ & 0.003 & 6.077 & LEV & 0.394 & & 0.729 & 1.483 \\
\hline ROE & -0.561 & $*$ & 0.026 & 0.571 & ROE & -1.026 & $* *$ & 0.02 & 0.358 \\
\hline МTB & -0.176 & $*$ & 0.012 & 0.838 & MTB & -1.468 & $* *$ & $<0.001$ & 0.23 \\
\hline SIZE & -0.234 & $* *$ & 0.001 & 0.791 & SIZE & -0.252 & & 0.092 & 0.778 \\
\hline REVG & -0.371 & & 0.114 & 0.690 & REVG & -1.261 & $* *$ & 0.003 & 0.0283 \\
\hline
\end{tabular}

Notes: Significance level: ${ }^{*} 5 \%,{ }^{* *} 1 \%$; DIV: Dividends paid out over equity; LEV: Leverage (debt/total asset); ROE: Return on equity; MTB: growth opportunity (market-to-book); SIZE: size of the firms (ln of total asset); REVG: dummy for companies with positive variation in revenues (growth/increase)

the results, except that the variable SIZE became significant at $5 \%$ in the Decline stage. We highlight that generally speaking, the specific changes not only refute the findings, but also reinforce them.

In addition, another robustness analysis of the results was performed by adding dummy variables for the economic sectors of businesses, according to the classification by Economática ${ }^{\circledR}$. The companies were divided into 19 sectors, of which the most representative were Electricity(14\%), Construction $(8.7 \%)$ and Steel $(7.6 \%)$. Generally speaking, we did not observe relevant changes in the results presented in Table 8. There was a maintenance of signs and magnitudes of all coefficients and only a few significances were altered. In the Introduction stage, the variable SIZE becomes significant only at $10 \%$, and the variable REVG becomes significant at $10 \%$. In the Shake-out stage however, the variable DIV stops being significant, the variable ROE becomes significant only at $10 \%$ and the variable SIZE becomes significant only at $5 \%$. Finally, in the Decline stage, the variable DIV stops being significant, and the variable SIZE becomes significant at 5\%.

\section{FINAL CONSIDERATIONS}

This study investigates the association between accounting and financial variables and firms life cycle stages, in order to validate the classification power of the established stages according to the methodological proposal by Dickinson (2011), using accounting and financial information. 
Table 9. Summaries of Expected Signs versus Achieved and the Hypothesis Analysis

\begin{tabular}{|c|c|c|c|c|}
\hline Variable & $\begin{array}{c}\text { Introduction } \\
\text { Expected/Achieved }\end{array}$ & $\begin{array}{l}\text { Growth } \\
\text { Analysis }\end{array}$ & Expected/Achieved & Analysis \\
\hline DIV & $-1-$ & Accept & $-1-$ & Accept \\
\hline LEV & $+1+$ & Accept & $+1+$ & Accept \\
\hline ROE & $-1-$ & Accept & $-1-$ & Accept \\
\hline MTB & $+/ \mathrm{NS}$ & $\mathrm{NC}$ & $+/ \mathrm{NS}$ & $\mathrm{NC}$ \\
\hline SIZE & $-1-$ & Accept & $-/ \mathrm{NS}$ & $\mathrm{NC}$ \\
\hline REVG & NA / NS & NA & $+1+$ & Accept \\
\hline Variable & $\begin{array}{c}\text { Shake-out } \\
\text { Expected/Achieved }\end{array}$ & $\begin{array}{l}\text { Decline } \\
\text { Analysis }\end{array}$ & Expected/Achieved & Analysis \\
\hline DIV & $-1-$ & Accept & - / NS & $\mathrm{NC}$ \\
\hline LEV & $\mathrm{NA} /+$ & $\mathrm{NE}$ & NA / NS & NA \\
\hline ROE & $-1-$ & Accept & $-1-$ & Accept \\
\hline МТВ & $-1-$ & Accept & $-1-$ & Accept \\
\hline SIZE & NA / - & NE & $\mathrm{NA} / \mathrm{NS}$ & NA \\
\hline REVG & NA / NS & NA & $-1-$ & Accept \\
\hline
\end{tabular}

NA: Not Applicable - NS: Not Significant- NC: Not Conclusive- NE: Not Expected

Leading international studies (MILLER; FRIESEN, 1984; FAMA; FRENCH, 2001; DE ANGELO et al., 2006; DICKINSON, 2011) found a relationship between firms life cycle with the policy of dividend and retained earnings, profitability, and revenue growth, capital structure and growth opportunity. This study sought to evaluate these findings in relation to listed Brazilian companies, by applying multinomial logistic regression analysis, to identify patterns of variables for the classification of companies in each of the cycle stages.

We observe that companies in the Introduction stage have more leverage when compared with companies in Maturity. Moreover, those in the Introduction stage pay out less dividends, have lower profitability and size when compared to those in the Mature stage. Regarding the growth stage, we see the same behavior in the Introduction stage, in relation to the variables dividends paid out, profitability and leverage. However, in relation to revenue growth we noticed that companies in the Growth stage present greater positive variation (increase) in sales than companies in the Mature stage. This shows that companies in these stages face natural problems as to their statement and search for growth, such as the lack of internally generated funds, even low profitability, low remuneration to shareholders, among others.

We also observed that companies in the turbulence stage pay out less dividends and have lower profitability and future growth opportunities when compared to companies in the Mature stage. As for leverage we see the exact opposite, i.e., companies in the Shake-out stage have higher debt levels. These results may be revealing that smaller companies with few future growth opportunities are more susceptible to the Turbulence stage and one of the ways to this stage is through uncontrolled debt, generating low profitability and distribution of results.

Finally, it appears that in the decline stage financial problems are represented by low profitability, few future growth opportunities and negative variations (decrease) in sales. 
In general, the results show that all variables displayed the expected behavior. Thus, the study took every chance, despite the inconclusive results for MTB. In other words, the results show greater leverage in the early stages of firms life cycle, fewer future growth opportunities in the Shake-out and Decline stages, greater profitability in the Mature stage, revenue growth in the Growth stage and decreased sales in the Decline stage.

It is worth highlighting that the expected results for the lower distribution of dividends for the Decline stage was not confirmed. This is also true for size, since the expected behavior of companies of smaller sizes is not confirmed for the Growth stage. Finally, we point out that we found no statistical significance for future growth opportunities in the early stages (Introduction and Growth).

Thus the results were consistent with the formulated hypotheses, since the independent variables can reflect the life cycle stages, seeming most often, significant for the model and consistent with the hypotheses and expected signs.

The limitations of the study are related to the rations and methods used. First, the use of data extracted from the cash flows statements restrict obtaining data previous to 2008 , since this statement was made mandatory only from this exercise onwards. Moreover, the actual classification method does not define the Shake-out stage, which is classified by the exclusion. Also, other ways of measuring the variables can provide results that will reinforce those presented or suggest expansion of the studies.

In future research, we suggest the use of other proxies, both for the independent variables as for the construction of the life cycle variable. We can also suggest for future research the study of the relationship between the life cycle and delisting or between the life cycle and financial problems. Finally, it would also be interesting to formulate sectorial studies.

\section{REFERENCES}

ALMEIDA, A. S.; LUZ, A. T. M. Associação entre Ciclo de Vida e Estrutura do Sistema de Controle Gerencial. In: ENCONTRO DA ASSOCIAÇÃO NACIONAL DOS PROGRAMAS DE PÓS-GRADUAÇÃO EM CIÊNCIAS CONTÁBEIS, 4., 2010, Natal (RN). Anais... NATAL: ANPCONT, 2010.

ALTMAN, E. I., , Financial ratios, discriminant analysis, and the prediction of corporate bankruptcy, Journal of Finance, n. 23, p. 589-609, 1968

AUZAIR, S.M, Organizational Life Cycle Stages and Management Control Systems in Service Organizations. International Journal of Business and Management, v. 5, n. 1, p. 56-65, p. 2010.

BEAVER, W. Financial Ratios as Predictors of Failure. Journal of Accounting Research, v. 4, pp. 71$111,1966$.

BROCHET F; NAM S; RONEN J (2008) The role of accruals in predicting future cash flS; and returns. Working paper Harvard University. Disponível em: Available at SSRN:http://dx.doi. org/10.2139/ssrn.1126022. Acessado em 18/01/2014.

BULAN, L.T.; YAN, Z. Firm Maturity and the Pecking Order Theory (Agosto, 2010). Disponível em: SSRN: http://ssrn.com/abstract=1760505 or http://dx.doi.org/10.2139/ ssrn.1760505. Acessado em 18/01/2014.

CARDOSO, R. L.;MENDES, A.DO CARMO, M. P.; MARTINEZ, A. L.; FERREIRA, F. R. Accounting Information Inconsistencies and Their Effects on Insolvency Prediction Models (March 8, 2010). Disponível em: http://ssrn.com/abstract=1567754 or http://dx.doi.org/10.2139/ssrn.1567754. Acessado em 18/01/2014

COSTA, G. DA S.; BOENTE, D. R. Análisedo perfil da produção científica sobre ciclo de vida no período de 2000 a 2011. Revista Ambiente Contábil, v. 4, n. 1, p. 106-119, 8 jun. 2012.

COULTON, J. RUDDOCK, C. "Corporate payout in Australia and a test of the life-cycle theory." Accounting and Finance, v. 51, p. 308-407, 2011.

DE ANGELO, H., DE ANGELO, L.; STULZ, R. "Dividend Policy and the Earned/Contributed Capital Mix: A Test of the Lifecycle Theory”. Journal of Financial Economics, p. 227-254, 2006. 
BBR

14,3

DENIS, D., OSOBOV, I. Why do firms pay dividends? International evidence on the determinants of dividend policy. Journal of Financial Economics, v. 89, p. 62-82, 2008.

DICKINSON, V. Cash Flow Patterns as a Proxy for Firm Life Cycle. The Accounting Review, v. 86, n. 6, p. 1969-1994, 2011.

DRAKE, K. Does Firm Life Cycle Explain the Relation between Book-Tax Differences and Earnings Persistence? In: AMERICAN TAXATION ASSOCIATION MIDYEAR MEETING: RESEARCH FORUM, 13, 2013, San Diego/CA. Anais... San Diego: ATA, 2013.

FAMA, E., FRENCH, K. "Disappearing dividends: changing firm characteristics or lower propensity to pay?". Journal of Financial Economics, v. 60, p. 3-43, 2001.

FÁVERO, L. P.; BELFIORE, P.; SILVA, F. L. da; CHAN, B. L. Análise de dados-modelagem multivariada para tomada de decisões. Rio de Janeiro: Campus/Elsevier, 2009.

FAZZARI, S. M.; HUBBARD, G. AND; PETERSEN, B. C., BLINDER, A. S., POTERBA, J. M., Financing Constraints and Corporate Investment. Brookings Papers on Economic Activity, v. 1988, n. 1, p. 141-206, 1988.

FAMA, E.F, FRENCH, K.R. Multifactor Explanations of Asset Pricing Anomalies. Journal of Finan$c e$, v. 51 , is. 1, p. $55-84,1996$.

DEMONIER, G. B. O impacto a restrição financeira na prática do conservadorismo contábil. 2013. 63 f. Dissertação (Mestrado em Ciências Contábeis) - Universidade Federal do Espírito Santo, Centro de Ciências Jurídicas e Econômicas, Vitória, 2013.

GORT, M.; KLEPPER, S. Time paths in the diffusion of product innovations. The economic journal, v. 92 , n. 367 , p. 630-653, 1982.

GREINER, L. E. Evolution and revolution as organizations grow. 1972. Harvard business review, v. 76, n. 3, p. 55, 1998.

HENDRIKSEN, E. S.; BREDA, M. F. V. Teoria da Contabilidade. São Paulo: Atlas, 1999.

HOSMER, D., LEMESHOW, S. (2000). Applied logistic regression. 2 ed. Nova Iorque: John Wiley \& Sons, 2000.

LESTER, D. L.; PARNELL, J. A.; CARRAHER, S. Organizational life cycle: A five-stage empirical scale. International Journal of Organizational Analysis, v. 11, n. 4, p. 339-354, 2003.

MILLER, D., FRIESEN, P. "A Longitudinal Study of the Corporate Life Cycle", Management Science, v. 30, n. 10, p. 1161-1183, 1984.

MILLER, D.; FRIESEN, P. Archetypes of Organizational Transition. Administrative Science Quarter$l y$, v. 25, n. 2 , p. 268-299, jun. 1980.

NECYK, G. A.; SOUZA, B. C.; FREZATTI, F. Ciclo de vida das organizações ea contabilidade gerencial.In: ENCONTRO DA ASSOCIAÇÃO NACIONAL DOS PROGRAMAS DE PÓS-GRADUAÇÃO EM CIÊNCIAS CONTÁBEIS, 1., 2007, Gramado (RS). Anais... Gramado: ANPCONT, 2007.

OWEN, S. YAMSON, A. "Corporate life cycle and M\&A activity". Journal of Banking \& Finance, v.34, p. 427-440, 2010.

PETRUCCI, C. "A Primer for Social Worker Researchers on How to Conduct a Multinomial Logistic Regression”. Journal of Social Service Research, v. 35, p. 193-205, 2009.

SUBRAMANYAM, K.R. The pricing of discretionary accrualsl, Journal of Accounting and Economics, v. 22, n. 1-3, p. 249-281, 1996.

WARUSAWITHARANA, M. "Profitability and the Lifecycle of Firms". Working paper. Board of Governors of the Federal Reserve System, 2013.

YAN, Z; ZHAO, Y. A New Methodology of Measuring Corporate Life-cycle Stages. International Journal of Economic Perspectives, v. 4, n. 4, 2010. 